\title{
Linking the knowledge and reasoning of dissenting actors fosters a bottom-up design of agroecological viticulture
}

\author{
Anne Moneyron ${ }^{1,2} \cdot$ LMC $^{2}$ - Westhalten group ${ }^{3}$ - Jean François Lallemand ${ }^{3}$. \\ Carine Schmitt $^{2}$ - Mireille Perrin ${ }^{2}$ Isabelle Soustre-Gacougnolle ${ }^{2,4}$. \\ Jean Eugène Masson ${ }^{2}$
}

Accepted: 30 July 2017 / Published online: 15 September 2017

(C) The Author(s) 2017. This article is an open access publication

\begin{abstract}
Wine growing has a high economic value globally, and vineyards, with their centenarian grape varieties, are an integral part of our societies. Yet with the use of spraying to control pathogens and weeds, mainstream viticulture has become a big pesticide consumer. Criticism of this conventional type of viticulture and its environmental/health impacts is increasing strongly throughout society. Until now, mainstream 'top-down' scientific-technical developments have focused on breeding for new varieties and on designing new agronomic models. In parallel, organic and biodynamic practices have been developing alternatives. Either way, changes do not develop on the expected time scale. We posit that the diversity of actors concerned, from winegrowers to technical advisers,
\end{abstract}

Jean Eugène Masson

Jean.Masson@colmar.inra.fr

Anne Moneyron

miguasha@wanadoo.fr

Jean François Lallemand

jeanfrancois.lallemand@wanadoo.fr

Carine Schmitt

cschmitt@colmar.inra.fr

Mireille Perrin

Mireille.Perrin@colmar.inra.fr

Isabelle Soustre-Gacougnolle

Isabelle.Gacougnolle@uha.fr

1 Tuque Rouge, 47500 Cuzorn, France

2 SVQV, INRA, Université de Strasbourg, 28 route de Herrlisheim 68021, BP 20507 Colmar Cedex, France

3 GIEE, 1 rue de Rouffach, 68250 Westhalten, France

4 Laboratoire Vigne, Biotechnologies et Environnement (LVBE, EA3991), Université de Haute Alsace, 33 rue de Herrlisheim, 68000 Colmar, France consumer associations, conservationists, elected representatives, citizens, and scientists, all contribute to the perpetuation of a constrained situation, through their differences in perspectives and practices, positions, knowledge, and reasoning. To untangle this situation, we brought together these dissenting actors. With a view to resolving the epistemological challenges, we then characterized four types of knowledge, along with the reasoning in play, and designed a tetrahedral model to legitimize and inter-relate them. This tetrahedron supported coconstruction of a collective epistemology after a paradigm shift, in which the dissensus became a resource on numerous occasions. We then highlighted masked double-bind situations and went further, developing a seven-step Argonaut to conduct the project. New practices were designed, to do away with herbicides and develop ecological grassing. They were implemented on a large scale in vineyards, within a short time frame, while enhancing the value of a neighbouring nature reserve. Projects currently underway in Switzerland, Germany, and France suggest that differences in knowledge are enriching, and yet that the reasoning at play fit with our tetrahedron model. We thus show that dissenting actors can dissolve agronomic/economic/ecological dilemmas, while acting under uncertainty, and foster agroecology development.

Keywords Viticulture $\cdot$ Research action - Transdisciplinary Knowledge $\cdot$ Reasoning $\cdot$ Actors $\cdot$ Dissensus $\cdot$ Environmental impact $\cdot$ Method $\cdot$ Model

\section{Introduction}

Grapevines are cultivated over a total surface area of 8 million ha worldwide. The landscapes shaped by winegrowers are not only an economic asset; they also provide them with social recognition. In many societies, an image and culture are 
associated with wine, and the precious qualitative varieties that are centuries old. Through the quest to preserve vines intact, by way of vegetative propagation, they have actually undergone a series of genetic changes concerning the colour of the berry, the aroma, and the shape of the bunch, thereby levelling up their initial value (Bacilieri et al. 2013; Stefanini et al. 2012). However, the bad news is that, of all the crops cultivated on a large scale, viticulture is the biggest pesticide consumer per acreage (Phytowelt $\mathrm{GmbH}$ for the European Commission 2003). As for all agriculture, evidence of significant harm to the environment is highlighted more and more (Foley et al. 2011; Tanentzap et al. 2015). Criticism of conventional viticulture has even gone as far as the law courts, when injuries to human health can be proven. Apart from the conventional viticulture itself, it is the farming/human food model which in recent decades has relied essentially on 'topdown' technical-scientific development that is being challenged. However, does the public know that vines must be pruned to blossom, and that it takes decades of constant and careful attention to produce great wines? Is it aware that it is impossible to harvest quality grapes without nursing the vine? This seems doubtful, in view of the simplistic ideas and representations circulating, including claims of pre-existing solutions and the idea that we should just 'let nature do its job'. What if the way out was (only) a matter of changing from one dominant viticulture model to another, from conventional practices to organic? Organic and biodynamic practices, which refuse synthetic molecules with a high environmental impact, now account for 4-5\% of all vineyards worldwide. Yet this surface area is growing by no more than 1-2\% annually, irrespective of the country (FIBL 2014). Furthermore, because of global warming, vine's phenology is undergoing change, as illustrated in the case of Pinot Noir, which in Burgundy is harvested 10 days earlier than in the fourteenth century (Chuine et al. 2004). Worse still, climate change also has impacts in the short term. Water stress has increased by up to $30 \%$ worldwide, causing yields to drop. Because they are unpredictable, these climate irregularities make it very difficult to control diseases. During dry springs, winegrowers are tempted to spray less against powdery mildew, as in Europe in 2014 and 2015. Yet the pathogen was nevertheless there, in the form of spores, and developed as soon as the first rains came, even though that rain was welcome. After the rains, it was too late to save the harvest. How can winegrowers design different wine-growing practices, faced with such uncertainty and constraints? In short, society, which criticizes viticulture, is not aware of winegrower's knowledge, while, at the same time, that knowledge is under threat by climate disorder. Tangled in this complexity, the lack of contradictory contributions underpinning research hypotheses has led to heuristic poverty (Pestre 2013). Responses to criticism regarding the environmental impacts of agriculture (Tanentzap et al. 2015) have focused on the development of new standards, forms of environmental governance, or support for transitions (Barbier and Elzen 2012; Duru et al. 2015). Research has also responded by designing new agronomic models, but without involving the end users (Prost et al. 2012). For grapevines, disease-resistant hybrids, GMOs (genetically modified organisms) or even gene editing are priorities (Dhekney et al. 2016; Malnoy et al. 2016). Yet if research's response to viticulture's impact on the environment modifies the centenarian varieties, will this not jeopardize what took centuries to develop, i.e. the plants, the image, and the associated knowledge? From this holistic overview, we posited that all actors, including winegrowers, researchers in the social sciences and in agronomy/plant biology, technical advisers, consumer associations, conservationists, elected representatives, and citizens, contribute to the perpetuation of a strained system through their diverse perspectives, practices, positions, and reasoning. Additionally, discrepancies in the legitimacy of the knowledge in play are a central question. Under such circumstances, should these same actors really be committed to designing awaited changes? If so, can participative research with its diverse practices be helpful (Marris and Rose 2010; Berthet et al. 2016)? Can scientists and wine growing consultants attribute the legitimacy of an innovation's genesis to a hybrid group, since they worry that participative research will jeopardize the foundations of research (Graur 2007)?

In 2003, in the midst of an acute controversy on GMOs and grapevines (Joly and Rip 2007), a hybrid group was set up as a Local Monitoring Committee (LMC). Scientists organized a field trial of GM rootstocks of grapevines and assigned the LMC to monitor it. The LMC however declined the task and instead adopted the core principle that all knowledge and values are legitimate (Local Monitoring Committee 2010). Reasoning other than that of the scientists was highlighted and legitimized. Specific questions raised by NGOs, winegrowers, and village mayor were taken into consideration for the first time. This approach led to the full reconstruction of the experimental plot, initially exclusively imagined by scientists. Furthermore, this research action opened up new research projects aiming to address specific questions through alternative viticulture practices, such as fallows, and through soil genomics studies, i.e. questions that scientists had never thought about nor taken into consideration before (LMC et al. 2010; Moneyron et al. 2012). The LMC paved a way for changing the premises of research with outside actors.

In 2009, the LMC raised a new question: was it possible to design more environmentally friendly wine-growing practices? This caused a shift from existing and controversial innovation (LMC et al. 2010) to a fuzzy question, rooted in the long-term relations between wine growing, humans, and the environment. It put the spotlight back on the agro-technical system, which was focused on ways to fight weeds and vine diseases, with its essentially deductive reasoning and 'topdown' approach, for the construction of knowledge and its 
transmission. This was clearly a constrained situation, as illustrated above. To untangle it, we first posited that bringing together all dissenting actors would unblock it. We then chose to acknowledge, above all, the experience of winegrowers, who have specific forms of action and reasoning. Thirdly, the project would not deal with accompanying actors on the route from one viticulture model to another. Instead, the aim was to design an agroecological system, based on the health of the vine in its environment. This approach raised major epistemological challenges for the production of knowledge on vines and viticulture practices, as well as for its legitimization, formalization, and transmission.

The tripolar theory of formation offered a way to grasp this project in all its complexity (Pineau 1989; Bolle de Bal 1996; Morin 2000). It also legitimized the diversity of reasoning at play (Denoyel 1999). These models, and the existing bibliographic references, helped both the LMC and the new actors organized in another hybrid group, in Westhalten, to build their research action (Barbier 1996). They went beyond the constraints, while co-constructing a collective epistemology, after shifting the paradigm. Within this paradigm, the numerous instances of dissensus became a resource. The group designed new vineyard practices and implemented them on a large scale (Fig. 1). It also contributed to the design of its project, designing a sevenstep Argonaut for its transdisciplinary research action, linking reasoning, and knowledge in a tetrahedron model, so that acting under uncertainty started.

\section{Materials and methods}

\subsection{Stakeholders and groups}

The stakeholders were the Local Monitoring Committee (LMC), consisting of a group of 20 persons committed since 2003 (LMC et al. 2010), and the Westhalten group, consisting of the chairman of the winegrowers' union and 20 winegrowers. Two of these were biodynamic winegrowers, one was an organic winegrower, and the others used conventional practices. Five of them made their wine and sold it, while the others delivered their grapes to three wineries. The other participants were the winegrowers' families, the mayor of the village, a member of a nature conservation organization Alsace Nature, a member of the organization Vignerons d'Alsace, a wine growing adviser from the Chamber of Agriculture, a retired wine growing adviser who supported the implementation of alternate grassing from 1970 to 1990 , an adviser from the local water agency, and a
Fig. 1 Vineyards fully controlled with herbicides, only in the balk, or tilled with a plough $(\mathbf{a}-\mathbf{c})$. They illustrate wine-growing practices in 20,75 , and $5 \%$ of acreage, respectively, for example in France. (Agreste study, 2013; http://agreste.agriculture.gouv.fr/ IMG/pdf/primeur336.pdf). The project's two choices of winegrowing practices after giving up the use of herbicides in the balk: ploughing (d) and a hawkweed cover, Hieracium pilosella L., (e). In hawkweed in bloom, other plants are present, suggesting preservation of plant diversity and thus answering biodynamic winegrowers' criticisms (f)
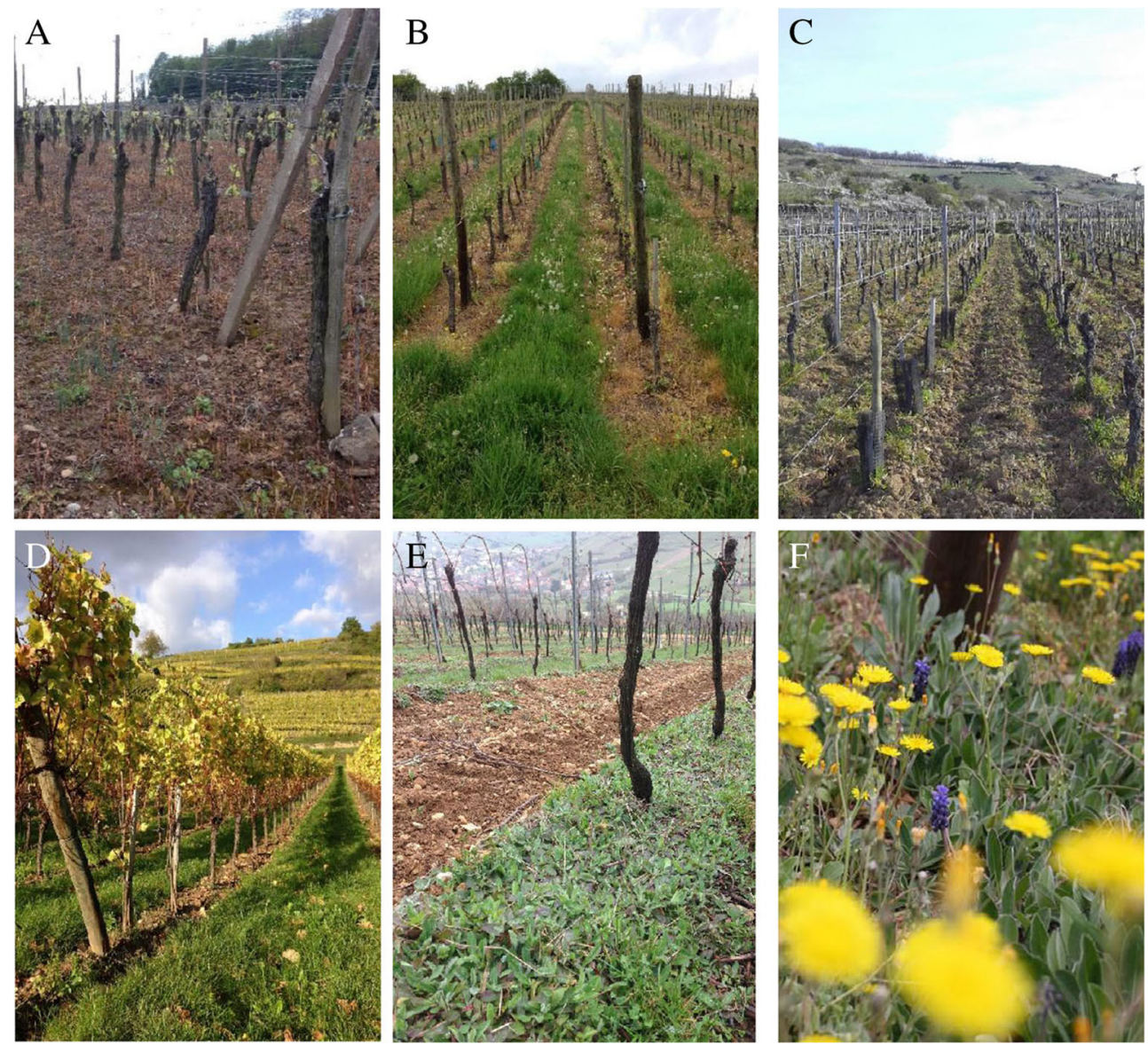
technical adviser from a cooperative winery. The scientists involved were an education and training science researcher (AM), an agronomist (JM) and, on an ad hoc basis, an anthropologist, a researcher in the epistemology of science, a biometrician and statistician, and students, who contributed but did not stay in the group

\subsection{Workshops and methods}

With the Westhalten group, we held individual open interviews (three to six with each participant) at the start of the project, then mid-term, and finally in 2016 with the social science scientists and students (education and training science, and epistemology). Individual interviews were held before the start of the project and are still ongoing with the agronomists (5 to 25 interviews, visits, meetings in the vineyards, with winegrowers alone, with their family or in groups). Interviews-workshops (4) were held with groups of three to four winegrowers, and with the scientists in human sciences, the agronomists, and the students. Interpretation-discussion-reflection was carried out, based on documents collected from individual interviews and/ or plot visits. Co-eco-training (3 days) on the vines' health and environment was delivered, bringing together all the actors of the group (workshop to study and understand the soils of their plots and their environment, statistical and biometric analysis, based on measurements taken in their vineyards; analysis of the expression of vines' defence genes, based on vine samples, debated interpretation-discussion, and collective writing). In 2016, we organized an evening event on agroecology, open to all, with all winegrowers. Over 120 winegrowers and citizens form the region attended. The event consisted of visits to the vineyards under change, after which two videos were shown, one illustrating the history of the village and its viticulture, including the problem of mudslides, and the other on the project itself. Open discussions were held with all the visitors.

A workshop was also organized on a 'zero herbicide' project. Full data were presented, with supportive statistical analysis answering the list of questions set at the start. Time was allowed for individual analysis and interpretation of the data. This was followed by a period in which each actor addressed the audience, thus highlighting the knowledge arising from their individual and collective experience. Co-construction of a consensus was articulated to the tetrahedron, so that all the reasoning and knowledge in play were interlinked.

With the LMC and the Westhalten group combined, there were three plenary meetings. All the interviews and meetings were recorded, and notes and photographs were taken (during meetings or in the vineyards). Most of these documents were shared with the participants orally (individual and collective discussions) and in writing (individually), and each person came with their own set of photographs and notes, relating to their farm. The personal interviews and these documents, which were notebooks in a way, facilitated communication between all the actors, along with the co-construction of the advances and key concepts of the transdisciplinary research action. For the collective co-writing, particularly of this article, workshops brought together members of the LMC and of the Westhalten group (30 persons), as well as scientists involved in the project, private companies that had contributed to it, and wine growing teachers external to the project (15 persons). A framework of the seven stages of the Argonaut emerged from this collective work, based on a set of cards representing the major events, and on quotes from the actors, based on 14 years of work. Each of the five mixed groups reconstructed and redesigned its Argonaut model, and then illustrated and explained it to the others. The article is a synthesis.

This research became transdisciplinary because all the knowledge contributed was legitimized, and we had to face obstacles, interruptions, and people leaving the project. Sometimes there were turbulent discussions, as well as lulls due to moments of heuristic failure. These difficulties were overcome in three ways: (1) through bibliographical work, to understand the situation, think differently and design; we thus gave scientific meaning to the process underway. This legitimized and defined more precisely what already existed and what constituted innovation in this transdisciplinary research action; (2) by staging and discussing concepts, like the tripolar theory of formation; and (3) by designing the tetrahedral model, which allowed us to establish tensegrity between the four knowledge sources and their underlying forms of reasoning. The actors appropriated these scientific foundations because they had experienced the project, having shaped it, and participated in the innovation. 'Novelty is needed for thought to intervene, and novelty is needed for consciousness to assert itself and for life to evolve' (Bachelard 1947). The present article describes this collective work. We describe the stages, citing the scientific articles that played a major role in the project, and quotes from the actors, which illustrate the steps in the reasoning and the action. For instance, the following quote by a member of the LMC in 2003: 'this is not a subject like any other, which is why we are here!'; 'Today, we could be at several other meetings starting at the same time, but we are here!'; and 'The challenge, and the motivation, for us, is that everything starts here'.

\section{Results and discussion}

Highlighting the tripolar model of formation was a founding event for the group (Pineau 1989). We experienced collectively that the first pole, 'heteroformation', was the most readily identifiable by all. It concerned education through the formal knowledge shared by others, and prioritized deductive 
reasoning (Fig. 2a). During its work meetings, the Westhalten group identified two other poles. As they shared their experience with one another, revisiting the sensory and direct formation of their perception of the world, the members of the group considered the ways in which they had constructed their decision-making rules for growing their vineyards. In other words, they looked at how their knowledge came to life, during their different experiences, and how they became rooted in the permanent reality of their material, natural, and imaginary environment: their eco-formation (Fig. 2a). They examined this knowledge, built in direct contact with the environment, without a human mediator, along with their ways of relating to things, during moments of introspection, and then reflexively mobilizing them in action, in other words, their self-formation (Fig. 2a). The tripolar model of construction, circulation, and connection of knowledge (Bolle de Bal 1996) proposed and discussed with the group shed light on, and legitimized, the two poles forgotten in our education: self-formed and ecoformed knowledge. These poles encourage abductive and transductive forms of reasoning (Denoyel 1999). Thus, the development of all the projects over a 14-year period, and their analysis, led us to highlight seven specific stages for this research action that we modelled as an Argonaut (Fig. 3).

A

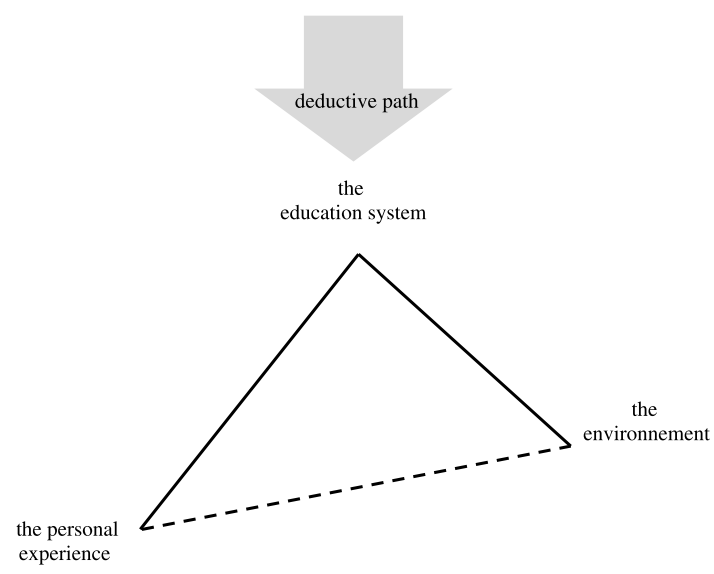

Fig. 2 a-b The tripolar model and the tetrahedral model to situate and support the knowledge produced and the forms of reasoning before and during transdisciplinary research action. The three sources of knowledge in the tripolar formation model (Pineau 1989) are linked (a). The fourth source, knowledge produced during the collective experiment, is connected to the others, thus forming a tetrahedral model imagined in our research action (b). The main forms of reasoning, according to

\subsection{Seven stages for an Argonaut-shaped method}

\subsubsection{Stage 1: bringing together the local actors involved}

This stage corresponds to the research action method developed by the LMC in 2003 (LMC et al. 2010). In 2009, the LMC discussed the poor performance of applications of the Ecophyto 2018 directive in vineyards. This was an opportunity to run new experiments with the coconstructed working method (ibid). Based on the comparative and collective analysis of life stories, and on discussions and information collected and situations observed, the LMC developed a research project and approached another group. The Westhalten winegrowers' union and associated actors took up this project. In order to form their wider group, the Westhalten winegrowers invited their parents to work on the project, based on their history. They identified and invited local, regional actors as well as scientists involved in relevant issues and controversies. Drawing on the 'Nominal Group' technique (Delbecq et al. 1975) and the 'Life Story' approach (Pineau 1983), each individual listed his or her main experiences concerning wine growing. A collective critical

B

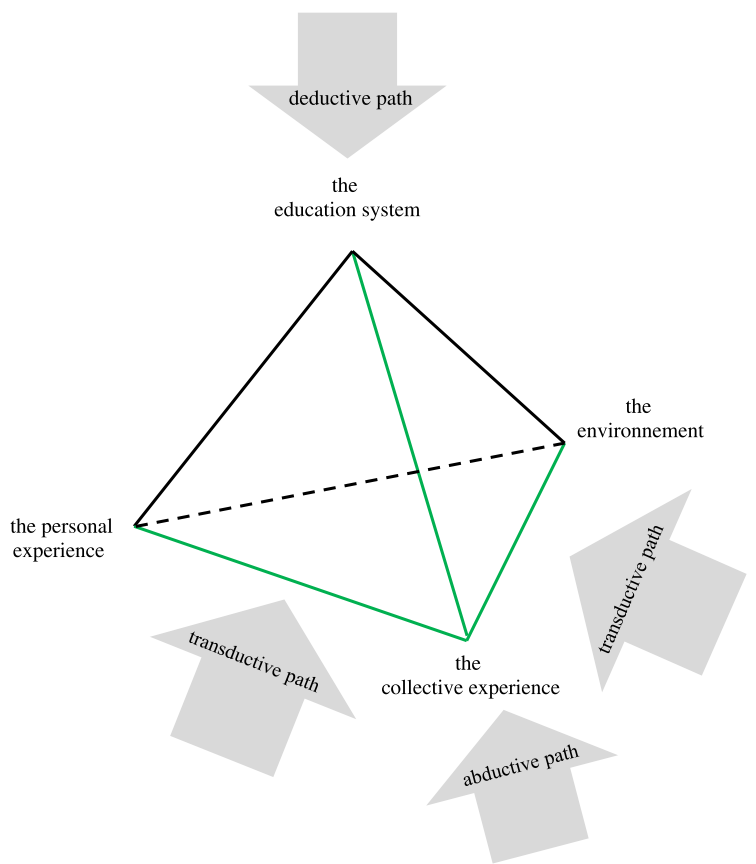

Denoyel (1999), informing the different types of knowledge (and the associated types of formation) are illustrated (arrows). At each stage of the Argonaut, the tetrahedral model situates the collective and individual epistemology, and the group pays attention to the preservation of both the links between the different sources and the tensegrity within this tetrahedron. Resolution of the tensegrity allows the group to move from one step of the Argonaut to the other 


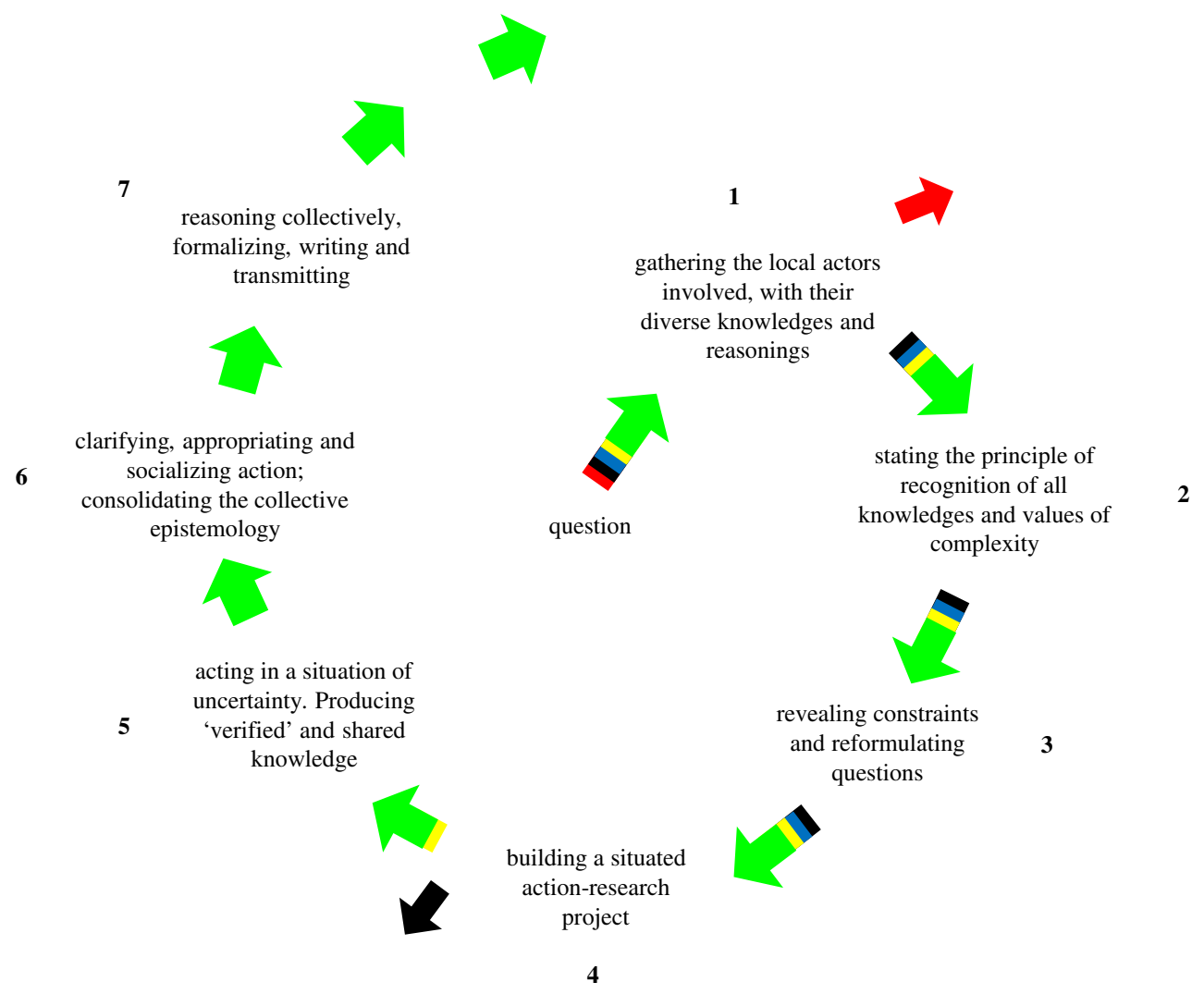

Fig. 3 The Argonaut, a model of the stages of research action project. The title of each stage describes the specific actions-changes. It also allows the group to situate itself within its project, with precise indicators. If a stage is not complete, the group returns to the tetrahedral model, and again reflects on the articulations between the four sources of knowledge and the associated forms of reasoning. Arrows illustrate the questions-projects. They show at which stage a project (with or without results) leaves the Argonaut. The ETI brought us putting together people

discussion ensued, focused on the 'black holes of knowledge' (Morin 2000) in person/vineyard/environment interactions, from the perspective of their agroecological transitions in wine growing. The group ranked the importance of the content of their statements. The actors debated links and disagreements. They co-constructed their questions, in relation to several issues: (i) consulting: 'We were given plenty of advice, we can see where it got us'; (ii) environmental policies, including Natura 2000, 'if protected plant species grow, soon we won't be able to enter our vineyards anymore'; (iii) different practices 'how is my vineyard going to react, I don't work like you'; (iv) the difficulty of the work 'for work, I have a sore back, I can't work like my parents did with a pickaxe!'; and (v) the purpose of the work: 'the quality of the wine, we shouldn't forget that if we work in a vineyard, it's to produce wine'. Based on a consensusdissensus dialectics, the discussion evolved, drawing on references from scientific publications, widely shared experiential knowledge, and models, from both agronomy and the humanities. Each issue was approached through into a LMC. LMC's projects dealt with redesigning the field-plot assay for GM-rootstocks (red arrow). The fallowing and soil metagenomics projects (black arrow) were co-constructed. However, scientists exclusively reason the project and its results. The 'vine health' and 'organic seeds' projects (blue and yellow arrows, respectively) are at stages 4 and 5 , respectively. The 'zero herbicide project' is illustrated by green arrow

areas of dissensus driving the mobilization. This exploratory debate recognized each person's cognitive, ethical, and pragmatic dimensions, as resources allowing the work and research hypotheses to evolve, and affording critical vigilance that supported the collective's functioning.

\subsubsection{Stage 2: stating the principle of recognition of all knowledge and values and of complexity}

The LMC and the Westhalten group broadened the initial principles, 'you are right, but I disagree', to move out of the 'double bind' situation (Bateson 1980; Kuhn 1990) by drawing on three propositions: (i) What if winegrowers' experiential knowledge were the linchpin of an agroecological wine growing project? (ii) What if the diversity of knowledge and practices were capitalized on? and (iii) What if we imagined and acted in the vineyards, with all the winegrowers, and more broadly, with all the actors, both responsible for the constraint and wishing to evolve? Questions soon emerged, regarding the method to implement, and its end goals: how to make the winegrowers' 
knowledge emerge, how to articulate them, and how to link them to knowledge from research and consulting? How to build legitimacy for all knowledge and all values? This difficult stage was a vulnerable moment, particularly for the winegrowers who were rooted in the dominant model of knowledge transmission (hetero-formation, Fig. 2a), as their personalities and values were laid bare. The members of the group reflected on the forms of reasoning they had been following, in connection with the stages of the construction of the knowledge, derived from the 'experiential learning process' (Kolb 1984). We had both sensory knowledge and expert knowledge corresponding to the sociotechnical expertise model (Ancori 2009). To imagine and convey what the proposition 'all knowledge is legitimate' meant to each participant, the group used the 'tripolar theory of formation' (Pineau 1989; Fig. 2a) and a collective epistemology took form. 'And so it's not so much about learning as also agreeing on the method'.

\subsubsection{Stage 3: revealing constraints and rephrasing questions}

Traumas resurfaced during stages 1 and 2. The hardship of unpredictable and uncontrollable natural elements unexpectedly transpired in individual narratives: violent storms, landslides from plots on a steep incline, mud invading the village. In response to this, for 40 years, agricultural consulting and research had promoted the standardized grassing of vineyards, based on ex situ trials. It took winegrowers decades of work and trials to rebuild and develop practices and knowledge, tailored to their uncertain environment (Callon et al. 2001; Dedieu et al. 2013; Moneyron 2013). They became experts in this new grassing agrosystem, largely developed in Alsace, with the exception of the balk, which was still sprayed with herbicides (Fig. 1). As a result, intense intergenerational and intercultural discussions and debates about the soil took place, as the latter proved to be a vital actor in the action research project, that is a non-human actor, in sociology of translation terms (Akrich et al. 2006), and a medium for material imagination (Bachelard 1947). Giving up herbicides was the choice prioritized by the group in its agroecological project. Still, 'If I grass more, my vineyard will suffer, but I want to stop using herbicides, but if I plough then the land will slide again'. This emphasized a double-bind situation (Bateson, 1980); it was also rooted in the history of the village. Parents of the winegrowers in the group updated this point by showing an old film. Viewing it proved to be a collective catharsis. Finally, we went beyond this double-bind situation, by refereeingand illustrating - to scientific fundamentals in the human sciences. Thus, during stages 1 and 2 (Fig. 3), the methodology was co-constructed; factors of paralysis and tension turned into cognitive impetus. A collective epistemology was presently being built in a different paradigm, beyond the constraints.
3.1.4 Stage 4: collectively building a situated research action project

The principle of the project was to draw on situated experiential knowledge. A winegrower suggested using hawkweed (Hieracium pilosella L.). This species is described as both having repulsive properties in relation to other plants and being able to cover the balk soil (Makepeace et al. 1985). A winegrower from the group described the knowledge he had developed over the last 3 years in his vineyards. The group criticized this, and tension mounted. In this context, the Westhalten group clarified its questions. The verification-veridiction of the information discussed was crucial: how valuable was this information when produced in other vineyards? What happened to trials carried out abroad in the past, by scientists or/and winegrowers? 'Anyway, in Switzerland, in any case, the soil of their vineyards, and the climate, are very different; it rains more than in our region, and they use more fertilizers, so...' The group noted that the other winegrowers had stopped using this plant, but the Westhalten group refuted all of their arguments. This stage was again a moment of fierce debate, particularly with the agricultural advisers and experts. All of the actors reverted to a minimum of acceptability in their thinking. Such times of doubt and debate offered space to communicate data. Thus, by considering all the information, the initial criticisms were voiced, while the values of all members of the group were respected. This clarified and situated the question, as well as the indicators required to define the experimental implementation in their vineyards, as accurately as possible. The uncertainties and vagaries that the group's winegrowers had learnt about, through their practices and observations, were also taken into account. During this co-construction, the group drew on other knowledge and highlighted its limits, namely the ability to produce hawkweed plots in quantities never required in Europe.

At this point, another winegrower disagreed with the idea of a plant cover for the balk. He wanted to leave the collective project, but eventually came back to propose another possibility: tilling the soil with a plough. The group, once again, fiercely criticized a local knowledge, even updating criticisms levelled at his father for decades, by the entire village. The winegrowers returned to their own tilling habits, which they discussed: 'you know, at home, I've got a whole collection of ploughs, but none of them are actually ok'. As for the hawkweed, the group co-constructed his project. It called in mechanization companies to propose soiltilling tools better suited to their project. After this fourth stage, the choice was between hawkweed cover in steepincline vineyards, and tilling the soil with a plough in others. Finally, winegrowers themselves to change 40 of the 200 ha they farmed, thus significantly changing their landscape and environmental impact (Fig. 1). 


\subsubsection{Stage 5: producing verified and shared knowledge}

By incorporating all levels of complexity of the situation in the project - reality as an included third principle, and the sensitive dimensions of reasoning and values (Dewey 2011) - this research action method became transdisciplinary. Attentive to the situation and to other individuals, the participants captured the heterogeneity of the forms of inference and knowledge at stake and recognized that of both individual and collective expectations. Meetings and interviews-conversations (Zeldin 1999) were held with the winegrowers, both in their vineyards, surrounded by the changing realities of their plots, and indoors. The same went for non-winegrowers. We took photographs and notes in situ, to capitalize on, to fuel new collective discussions, and to anticipate potential needs for research questions. This collective reflexivity provided data on the transition towards agroecology, in agronomic and human terms. Both personal and collective transformations affected action and research, because they contributed to the project. This method integrated constant confrontation with a changing reality and the collective construction of situated truth. A consensus truth and a correspondence truth (Habermas 2002) recognized the validity of both facts and values. In these key moments, according to the methodological principles identified and developed, the difficulties in including the complexity of the reality-which was an epistemological choice by the group-fostered the emergence, elaboration, and adjustment of research hypotheses that initially had been unimaginable. We considered all knowledge in relation to its role as an interface between person/environment, information, and knowledge (Legroux 1989). This transdisciplinary research action method tackled the complexity of life forms and proposed frameworks and tools, other than those of the analytical approach, which renewed the nature of the objects of knowledge (Latour 2009). From this standpoint, each party held complex fragments of truths and doubts that were necessary to the construction of a sounder argument. They drew on deductive, inductive, transductive, or abductive approaches, all validated by theoretical frameworks developed in collective epistemology (Denoyel 1999).

\subsubsection{Stage 6: clarifying, appropriating, and socializing action; consolidating the collective epistemology}

The Westhalten group's desire to carry out research on the complex relations between the vineyard, its health, and its environment, required the co-construction of a transdisciplinary research action based on the collective epistemology. It allowed for integration of the complexity of the human agroecological dimensions of training for another viticulture and knowledge sharing. By approaching the project through their life stories, which resituated their priorities on the land, including storms and mud, and not just on technical imperatives, the winegrowers set the terms of their actual and imaginary relations with long-term environmental reality, as a factor of the construction of their knowledge (Moneyron 1997). When students from a viticulture school in Switzerland visited, and during demonstration workshops open to all actors in the wine industry, the members of the group said: 'But what are we going to tell them? We have nothing, what do we do?' In the vineyards, changes in practices linked to the project were just a few months old. Faced with the visitors' questions, the discussions quickly veered from technical explanations to stories about their professional life, their desires, their choices, their parents' practices, that is, the 'social, emotional, and especially temporal dimensions of life' (Schön 1994) informing the decision-making. When one visitor expressed doubt, saying, 'This is not going to work', a winegrower from the group replied: 'But why do you say that? Do you have arguments, proof, experience, an explanation to tell me that it's not going to work?' This arguing took the visitor aback. One student told the group: 'your project is philosophical'. For the 100th anniversary of the winegrowers' union, the chairperson gave a speech and showed the film on the village's history. The group, and the village invited, discovered the long collective history of the vineyard, winegrowers and their knowledge, and of the village and the elements, the land, storms, the mudslides, and so on. What made their identity and led them to think and act collectively? The agroecology project, which started in 2012, is rooted in this history. A workshop with four other winegrowers' unions wishing to develop their own agroecology project was organized, and the production, in spring 2015, of a film presenting the Westhalten project, were milestones at which to present and discuss the forms of reasoning and theoretical models in play, in our project. In these multifarious moments of interactions and reflection, the group became aware of how far it had come, as an outcome of the epistemic changes that had taken place. All these interactions with society were an opportunity to gain awareness in three ways, through 'presenting, discussing and reflecting' (Denoyel et al. 2009).

\subsubsection{Stage 7: reasoning collectively, formalizing, writing, and transmitting}

The transdisciplinary research action was a source and factor of change through its knowledge production. Stages 6 and 7 were closely linked. The actors' needed to formalize, write, and transmit what constituted the different transitions of their method that were at play, throughout the research. We published a first article, whose lead author was the LMC (LMC et al. 2010). The publication was an innovative collective exercise for all. It was also a form of response to the reality of society. It was a reaction to adversity, consolidating the critical thinking driving the group. As some LMC members pointed out: 'If we hadn't published, there would be nothing 
left of everything we did'. For the Westhalten group, this materialized in 2015 with the publication of an article written by its members, and with the production of a film (le groupe repère et al. 2015). It is important to stress this collective dimension of the writing, as it is not self-evident. In our research action method, it was an integrated stage, inseparable from the project. We planned and initiated the writing process from start of the transdisciplinary research action, to better capture the complexity. The article, formalized here, once again showed us how crucial this stage is in the research action method. In the vineyards, the experimental plots collectively imagined are currently yielding results that answer questions addressed in stage 4 . We are currently reading and analysing these data, relying on the collective epistemology of the group developed in the successive workshops. Thus, we embrace complexification, putting all forms of reasoning in play, and thus not giving space to the usual epistemic conflicts found in stakeholder groups (Audoux and Gilet 2011). The goal is indeed to produce agronomic conclusions, ways to share abroad, and ways to accompany other winegrowers in implementing agroecology in their vineyards. Stage 7 of the method finalized the Argonaut design. It was not the last stage closing the loop, but the exploratory opening of the Argonaut, which at this stage, could initiate a new spiral able to integrate new questions and new actors to contribute to the researchaction.

\subsection{A tetrahedron model to articulate different knowledge and forms of reasoning}

The group developed its own epistemology, within a new paradigm, and thus resolved the double-bind situations that it faced. In addition to the initial knowledge, legitimized through the tripolar entries model (Pineau 1989, Fig. 2a), new knowledge's arose in the course of action. This raised new questions with respect to their legitimacy and improved concepts of formation for sharing. In order to legitimize this fourth category of knowledge, we designed a tetrahedral model. It linked these emerging knowledge, along with the associated modes of inference, to the pre-existing three poles (Fig. 2b).

The tetrahedron allowed us to bring together the different reasoning in play in this group of actors with divergent perspectives, and reinforced the collective epistemology. Thus, in the lengthy co-construction of the project and its implementation, collective experience became a source of new knowledge and forms of learning, for each of the actors. Both situated and generic knowledge constantly grew and became more and more precise, not as a way of simplifying experiential knowledge and thus concealing overall reality, but through a real process of anthropo-formation (Wulf 1999; Pineau 2003) of the complex person-knowledge-environment relationships. The hybrid nature of the group, and its relations with networks of actors, made it possible to constantly articulate deductive, inductive, transductive, and abductive reasoning in our tetrahedral model (Fig. 2b).

While the project developed in the vineyards, obvious changes occurred, with respect to perceptions of the balk, at first. Numerous questions, either from winegrowers, inhabitants of the valley, or advisers, challenged the group members. In this uncertainty, the changes destabilized them. Actors' links to the four poles of the tetrahedron were imbalanced, with quite distinct positioning within the model, depending on the group member. Interviews and group meetings allowed the reflexivity in play to be characterized (Schön 1994). To highlight and better emphasize this phenomenon, we organized more visits of the experimental vineyards. Thus, through socialization of the project, a formalization of argued speech arose for each of the actors. We also designed specific formations to bring all the actors back to the theoretical barycenter of the tetrahedron, where collective epistemology developed at best. Collective writing and the creation of the film on our project contributed further (le groupe repère et al. 2015; http://www.dailymotion.com/playlist/x4jpty_ Alimentation-Agriculture_productions-et-filieres $/ 1 \#$ video= x4hzo01).

Finally, co-designing of the Argonaut, and theorization of the research-action with the tetrahedron were discussed again, within a 45-people workshop. Later in the project, unexpected issues arose, including criticism of the standard grassing used for decades in wine rows, and the idea of giving up the fight against pathogens and instead moving towards an approach that prioritized 'wine health'. In the course of the Argonaut's successive cycles for each issue, the collective epistemology was strengthened. Our scientific framework was based on the knowledge stemming from the research action (Barbier 1996), and this ensured continuity and a form of situated collective truth. Ultimately, the actors went beyond the double-bind constraints and experienced satisfaction, as their collective heuristics led to concrete changes in their life as a winegrower.

\subsection{The Argonaut and the tetrahedron put to the test with new questions}

While the transdisciplinary research action was underway, 2014 and 2015 saw considerable water stress on vineyards, with harvests dropping by up to $30 \%$ and causing strong tension among winegrowers. Tilling the balk, or hawkweed covers, could be factors exacerbating water stress, as both killed or competed with vine roots developing just under the surface (Smart et al. 2006). Instead of calling into question the changes they had made, the members of the group returned to the issue of water stress, but this time, in connection with plant biodiversity in their vineyards. Actually, their vineyards farmed without any herbicide were very large. Which plant species would recolonize the vineyards and what would their impact be? Would there be spontaneous plant diversification? 
How long would it take? 'But once you have introduced this hawkweed, you are putting a monoculture into a monoculture', argued a biodynamic winegrower. ' $\mathrm{Oh}$, because where you are, there's plant diversity? Wheatgrass and tall grass, well... the only ones that resist water stress', answered the members of the group. 'Yes, that's kind of true; in fact I've had to plough all the grassing to save the vineyard this year'. The question moved further. 'Well why don't we go on the heath, there're plants up there that hardly grow and as soon as it rains they come out', 'If we went to fetch seeds to sow in our vineyards, those ones would compete less with the vines when it's too dry'. This debate reignited the strong controversy about vineyards and the surrounding dry moor, a protected Natura 2000 area. At this stage, the member of the NGO Alsace Nature pointed out that the area was protected, and that collecting seeds was prohibited. To emphasize further the difficulty, a winegrower said 'In any case, I'm not with you... if they find rare plants in my vineyard, I won't even be allowed to go there anymore...' The collective epistemology, operating through the Argonaut, had raised a question that none of us had thought about before. The group found itself in a situation of disagreement and tension. This question furthermore revived the painful memory of the creation of the protected area.

This new question also put to light the complex constraints in play (Bateson 1980). The collective epistemology developed during the first Argonaut cycle, with the idea of zero herbicide balk, led us out of the deadlock. The group reformulated individual questions into a shared concern (stages 1-3, Fig. 3): How to develop drought-resistant grassing between the rows, with natural, local seeds that will not compete with the vines? And emerging obstacles popped again: How to overcome multiple regulations regarding wild species, their preservation, their multiplication, and who has competence for multiplying such plants? The group appealed to a botanist from the protected area and a seed manufacturer, with expertise on the production of seeds from wild species. Thus, a initially unexpected question which emerged from the reasoning and practical observations, around giving up herbicides in the balk, turned into a new project, which is currently developing over 20 ha, revisiting stages $1-5$ of the Argonaut (Fig. 3; Fig. 4). Once again, new questions popped up. What about possible negative impacts of the flowering of our ecological grassing, as it would attract honeybees. 'How will the public react, when we will spray with fungicides?' asked a winegrower who was also a beekeeper. This constant emergence of questions and obstacles illustrates the dynamic of this collective epistemology, and the legitimacy of all questions. It also reflects that the group was truly fully engaged in acting in uncertainty (Callon et al. 2001; Dedieu et al. 2013; Moneyron 2013; Ancey et al. 2013).

After this new project had been co-designed, the question of the vineyard's health, based on the impact/command of the

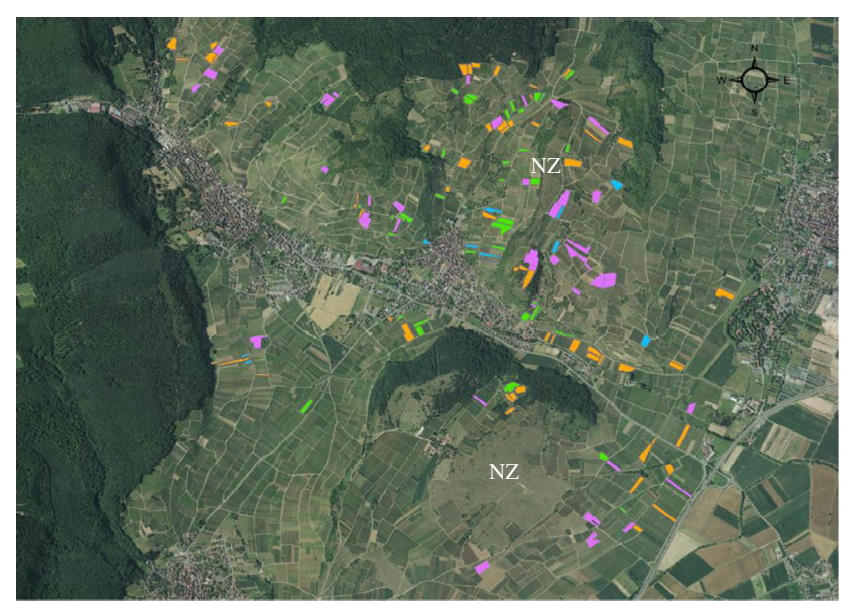

Fig. 4 The research action project in the vineyards of Westhalten and the 'Zone Natura 2000' moors (ZN) vine plots of the winegrowers involved in the research action project are in green and orange when hawkweed or tilling, respectively, are used instead of herbicide's sprays in the balk, since 2013. In violet, vine plots engaged for changing conventional to ecological grassing's with plants from the Zone Natura 2000. In blue, vine plots engaged for a currently developing project on vine health

TFI (Treatment Frequency Index for Ecophyto 2018) formulated 5 years earlier by the LMC, was raised again. The Westhalten group reconsidered it in concrete terms on its territory, 'But in any case, we've been trying to reduce fungicides for years, we can't do better'. This immediate balking reaction reflected the strong tensions and disagreements between actors, based on lived experience of the vineyard health/ environment relationships, which moreover differed between conventional, organic, and biodynamic winegrowers. We faced comments addressed to scientists, such as: 'Stop breaking everything down into pieces in your studies, look at the bigger picture', and 'In our vineyards, we see the vine's response and we decide, we've been doing things like that for a long time'. Scientists replied: 'but what is the impact of your winegrowing practices on the genes involved in plant health, which we are studying? Perhaps nothing good?' We witnessed a complete renewal of disagreements between the group's members. Once again, we revealed obvious but also masked constraints. The group resumed stages 1-3 (Fig. 3). Based on the four poles of the tetrahedron, it ensured the tensegrity of all the knowledge and forms of reasoning present, and identified those that could be leveraged. We also untangled part of the black holes in the knowledge of each of us (Morin 2000).

A project dealing with vineyard health is currently being co-developed (stage 4, Fig. 3; Fig. 4), still following the same research action method. The biologists, who studied vine health in laboratories (Romon et al. 2013), started addressing the issue in a more holistic way. In collaboration with the group, the project deals with the vineyards in their environment. Biochemical and molecular issues, human issues, that is to say in individual and collective sensory observations, and normative indicators are examined. 'The soil structure and life 
have such influence on the plant, fortunately we started with the zero herbicide project two years ago', 'but you think that the soil has changed?' These comments showed that when complexity and dissensus were taken into account, vine health could be envisaged differently, by departing from the 'fighting against pathogen' conventional path for, instead, integrating vine/environment/human relationships. Once, again, all the actors' critical arguments and reasoning anchored in the equilateral tetrahedron, in which the four types of knowledge are in constant tensegrit.

In response to the multiplicity of knowledge, timescales, values as well as singular and collective experiences, the four knowledge poles' respective importance evolved, thus changing the tensegrity within the tetrahedron. These periods of uncertainty are a necessarily learning curve. The actors' relationships, thoughts, are ways of giving meaning to the situation changed, as in the case of allosteric relations, which ultimately change the persons, after what is a collective formation (Giordan 1997). Therefore, group members addressed new questions differently, through the successive Argonaut cycles.

\section{Conclusion}

Worldwide, actors from different worlds come into conflict over the use of arable/natural space, and the environmental impacts of the dominant farming model can no longer be denied (Tanentzap et al. 2015). Will negotiating and defining new forms of governance be enough to untangle such complex issues? Is it that inconceivable that society could contribute to resolving them, not only through its choices, but especially by recognizing the nature and diversity of its knowledge and reasoning? For the last 14 years, through several projects on vine health and the environment, research action groups have been building a collective epistemology, within a new paradigm where all the stakeholders agreed to step in. This enabled us to reveal double-bind situations, which are obstacles to change and to action. The transdisciplinary research action developed allowed for human and agronomic changes within a short time and across over 60 ha of vineyard, out of the 200ha they grow, near a nature reserve (Fig. 4). From the experimental point of view, our method has the shape of a sevenstage Argonaut, drawing on a tetrahedral model. This model characterizes the collective epistemology in play and legitimizes the different forms of knowledge and reasoning of the actors. Dissensus in particular is no longer an obstacle but becomes a resource for research and for agroecological changes. Interestingly, in our study, double-bind situations emerged sequentially as the seven-step Argonaut work developed, for instance soil and mudslides, the drying up of the moor, and abiotic stress due to climate deregulation. These are nonhuman actors (Callon 1988). Starting the first day with individuals' knowledge on vineyards, we reached the landscape level, that is to say 'the construction of a shared world' (Audoux and Gilet 2011). The periods organized for reflexivity allowed for a back and forth from anyone's vineyard to the landscape and society, similar to the experience at the 'open to all evening on agro-ecology' in 2016. This reflexivity changed the image that the winegrower's were used to having about themselves, with respect to their vineyard, the moor, and even society. The tetrahedron anchored their reasoning under change. In contrast to other participative methods (Hubert et al. 2013; Berthet et al. 2016), here the model - the tetrahedronwas collectively designed, as a major result of the research action. It anchored the collective epistemology and favoured the action under uncertainty. Still, broadening such research action methods to other viticulture groups and countries is a key issue. First, the agronomic solutions designed for zero herbicide viticulture (hawkweed and tilling with a specific plough), as well as the knowledge accompanying these viticulture practices, are ready for transfer to other winegrowers. The same stands true for ecological grassing, as long as the soil and climate are adapted. Another collective project is developing in Alsace. It has reached step 3 of the Argonaut (re-formulating the initial question). We have also started two research action projects in Germany, and one in Switzerland (Interreg Agrofrom). The local history and sociology of viticulture are quite different from those in France, as are the vines, climate, and economic conditions. These particularities have popped up from the start. We are however finding that such differences are advantageous as they diversify and enrich common knowledge. Along the seven-step Argonaut, they are translatable into reasoning, which fit with the tetrahedron model. This suggests that implementing our method abroad may further develop general knowledge on viticulture practices and on their environmental impacts, in addition to fostering relations between the numerous actors, through a more universal and shared feature: human reasoning. In other words, the sociocultural characteristics of viticulture in different countries tend to illustrate differences, whereas the tetrahedron model structures what is common to all.

Beyond these examples on viticulture, the stakes extend to all agriculture. What is the legitimacy of knowledge arising from the scientific field, versus legitimacy of other knowledge, if we think global? At this scale, the rift between society and science is such that it is no longer a matter of building bridges (Agre and Leshner 2010). Indeed, society is joining in a shared construction of a possible and situated truth, especially regarding common goods, air, water, biodiversity, and farming. It is calling into question the science/truth relationship, which on a fundamental level raises epistemological questions (Pestre 2013). To address these issues, numerous participative methods are in play to develop other agronomic models. They, however, have evolved quite far from the initial research action, as defined by Barbier (Barbier 1996; Hubert et al. 2013). Comparison between participatory design methods suggests 
differences in the involvement of stakeholders, the role of learning, the status of knowledge, and the implementation of (existing) models (Berthet et al. 2016). In 'fuzzy methods', frontier objects and establishing a 'common language' are prerequisites to the project's success (Lang et al. 2012). However, the prevalence of the hypothetic-deductive model remains, with its single mode of inference. The main issue is still consensus, often as a preliminary step. Thus, the legitimacy of scientists' and experts' knowledge is still predominant, as are pre-conceived sociological and agronomic models (Prost et al. 2012). This eventually leads to epistemic conflicts within stakeholder groups (Audoux and Gilet 2011). If we discuss these participative methods, with a focus on dissenting actors, what relations do they have to the Argonaut and the tetrahedron? The dissensus is taken into account in the framework of ETIs (Joly and Rip 2007) or citizens' conferences, as in stage 1 of the Argonaut. However, the group does not enter stage 2 (Fig. 3). In farming, participatory seed-selection approaches only involve farmers who disagree with the standard farming model, and therefore do not enter stage 1 of the Argonaut. Following an ETI, the LMC imagined the 'principle of recognition' (Honneth 2006) and of 'non-utilitarian' convergence (Caillé 1989) of all knowledge. By rethinking the experimental conditions of the rootstock trial, it reached stage 4 of the Argonaut. The new questions collectively debated during all the stages were also translated into new fallowing and soil metagenomics projects (LMC et al. 2010; Moneyron et al. 2012). However, since then, scientists have opted out of these projects. The results produced have consequently fallen outside the Argonaut, as they were not discussed within the LMC in action (Fig. 3). Additionally, starting with a broad question stated by the LMC and its reformulation by a group (Westhalten), with a situated meaning, informed by the collective history, was a strong indicator of the success of stages one to three of the Argonaut. At each of these stages, this method offered ways in for external resource persons: (i) to address specific questions or (ii) to spontaneously become involved by renewing the dissensus: 'It's time to bring in the newbies; we're starting to agree with each other too much'. These movements of actors enriched the reasoning. They afford access to other networks of actors, to further sources of diversification of thought (Ancori 2005; Ancori 2012). Here, we suggest that research can play a key role in the changes that many are awaiting. However, it is a different kind of research, involving new relations with all the actors. The result is a de-hierarchized and bottom-up knowledge production system, where the recognition, mobilization, and circulation of all knowledge will be prioritized (Callon 1988). With this method, spaces for discussion and the construction of collective epistemologies open up. The scientific truth is reinforced (Rose 2012), as it is co-constructed by drawing on multiple forms of reasoning, as long as they are anchored to the tetrahedral model. Our transdisciplinary action research supports a society of knowledge, not so much as it was envisaged by W. Colglazier (2015), but rather as the development of an innovative democracy project, in which research recovers its vital role (Rose 2012; Stirling 2012). On such a path, the way questions are built matters (Bachelard 1999) or, in other words, as a winegrower said, 'If, we go about one thing differently, it changes virtually nothing, but ultimately virtually everything'.

Acknowledgements We thank Marianne Cerf for her amendments, suggestions, and encouragements for the writing of this article. Special thanks to Bernard Ancori for taking part in the start of the project and for his epistemology course at J.E.M. at the university. We would like to thank Yann Poeta and Sophie Champoiral, epistemology of science students, as well as Johann Fuchs and Leo Diringer, agronomy students, and M. Mermet for Fig. 4. We would also like to extend our thanks to the sociology lecturer Frank Hausser, the eco-anthropologist Elise Demeulenaere and the researcher in agronomics and biometrics Marc Lollier, for their ad hoc contributions. Thanks to the three successive presidents and directors of AVA for support in this long-run project. Many thanks to all the actors of the LMC and Westhalten groups: Bach F, Bauer J, Boesch G, Breuzard M, Champion E, Dorfner V, Frissant P, Goulby JP, Guery M, Hartmann C, Herth A, Klein C, Lemaire O, Muller J, Rohfritsch S, Roth A, Sipp E, Valentin S, Vezien JL, Vigneron S. Westhalten group: Attard J, Boesch M, Breuzard M, Burgenath M, Bursin A, Dauer E, Diringer S, Hetsch R, Huntzinger B, Isner P, Kaepfer B, Koehler C, Lallemand JF, Lallemand JF, Lassablière R, Miclo Y, Montavon P, Ribeiro S, Rominger C, Rué P, Schäfer P, Schatz G, Schatz V, Schermesser F, Schlegel JL, Schmitt D, and Wisselmann F. 'but all this would never have happened if we hadn't been together, so let's sign as a group', as they said.

\section{Compliance with ethical standards}

Funding This project was funded by the REPERE programme of the Ministry of Ecology and Sustainable Development, and by the $\mathrm{SmaCH}$ INRA metaprogramme. For the agronomic part, it was partly funded by the Agence de l'Eau Rhin Meuse and the Conseil Interprofessionnel des Vins d'Alsace and the Conseil Régional d'Alsace. The AVA (Association des Viticulteurs d'Alsace) has been involved in the entire project since 2003.

Open Access This article is distributed under the terms of the Creative Commons Attribution 4.0 International License (http:// creativecommons.org/licenses/by/4.0/), which permits unrestricted use, distribution, and reproduction in any medium, provided you give appropriate credit to the original author(s) and the source, provide a link to the Creative Commons license, and indicate if changes were made.

\section{References}

Agre P, Leshner A (2010) Bridging science and society. Science 327(5968):921. doi:10.1126/science.1188231

Akrich M, Callon M, Latour B (2006) Sociologie de la traduction-textes fondateurs. Presses des Mines Éditeur. doi:10.4000/books. pressesmines: 1181

Ancey V, Avelange I, Dedieu B (2013) Agir en situation d'incertitude en Agriculture. Regards pluridisciplinaires au Nord et au Sud, Paris, P.I.E. Peter Lang Ecopolis 17:13-17 
Ancori B (2005) "Analogie, évolution scientifique et réseaux complexes", Nouvelles perspectives en sciences sociales. Revue internationale d'analyse complexe et d'études relationnelles 11:9-61

Ancori B (2009) Expertise et citoyenneté : les grecs anciens et nous. De l'Agora antique aux forums hybrides modernes. Revue d'anthropologie des connaissances 3(3):485-529. doi:10.3917/rac. 008.0485

Ancori B (2012) "La production et la circulation des connaissances scientifiques et des savoirs profanes dans nos sociétés techniciennes" in Darbellay, F. (ed.), La circulation des savoirs. Interdisciplinarité, concepts nomades, analogies, métaphores, Editions internationales Peter Lang : 203-240

Audoux C, Gilet A (2011) Recherche partenariale et co-construction de savoirs entre chercheurs et acteurs: l'épreuve de la traduction Revue Interventions Economiques https://interventionseconomiques. revues.org/1347

Bachelard G (1947) La terre et les rêveries de la volonté. José Corti, Paris

Bachelard G (1999) La formation de l'esprit scientifique. Paris, Librairie philosophique Vrin (1ère édition : 1938)

Bacilieri R, Lacombe T, Le Cunff L, Di Vecchi-Staraz M, Laucou V, Genna B, Péros JP, This P, Boursiquot JM (2013) Genetic structure in cultivated grapevines is linked to geography and human selection. BMC Plant Biol 13:25. doi:10.1186/1471-2229-13-25

Barbier R (1996) La Recherche-Action. Anthropos, Paris

Barbier M, Elzen B (2012) System innovations, knowledge regimes, and design practices towards transitions for sustainable agriculture. INRA Editions, Paris

Bateson G (1980) Théorie de la double négation, vers une écologie de l'esprit, Seuil

Berthet ETA, Barnaud C, Girard N, Labatut J, Martin G (2016) How to foster agroecological innovations? A comparison of participatory design methods. J Environ Plan Manag 59(2):280-301

Bolle de Bal M (1996) Voyages au cœur des sciences humaines. De la Reliance, Paris, L'Harmattan

Caillé A (1989) Critique de la raison utilitaire. La découverte, Paris

Callon M (1988) La science et ses réseaux. Genèse et circulation des faits scientifiques. La Découverte, Paris

Callon M, Lascoumes P, Barthe Y (2001) Agir dans un monde incertain. Essai sur la démocratie technique. Le Seuil, Paris

Chuine I, Yiou P, Viovy N, Seguin B, Daux V, Le Roy LE (2004) Historical phenology: grape ripening as a past climate indicator. Nature 432(7015):289-290. doi:10.1038/432289a

Colglazier W (2015) Sustainability. Sustainable development agenda: 2030. Sep 4; no 349(6252):1048-1050. doi:10.1126/science. aad2333

Delbecq AH, Van de Ven AH, Gustafson DH (1975) Group techniques for program planning: a guide to nominal group and Delphi processes, AL. Glenwiew publisher

Denoyel N (1999) Alternance tripolaire et raison expérientielle à la lumière de la sémiotique de Peirce In: Revue française de pédagogie 128:35-42

Denoyel N, Guillaumin C, Pesce S (2009) Pratiques réflexives en formation. L'Harmattan, Paris

Dewey J (2011) La formation des valeurs, Paris. Les empêcheurs de penser en rond

Dhekney SA, Li ZT, Grant TN, Gray DJ (2016) Somatic embryogenesis and genetic modification of Vitis. Methods Mol Biol 1359:263-277. doi:10.1007/978-1-4939-3061-6_11

Duru M, Thérond O, Fares M (2015) Designing agroecological transitions; a review. Agron Sustain Dev 2:127-138. doi:10.1007/s13593015-0318-x

FIBL (2014) "the world of organic agriculture", 2014, Biofach, Etude du FIBL, http://www.fibl.org/fr/

Foley JA, Ramankutty N, Brauman KA, Cassidy ES, Gerber JS, Johnston M, Mueller ND, O’Connell C, Ray DK, West PC, Balzer C, Bennette EM, Carpenter SR, Hill J, Monfreda C, Polasky S,
Rockström J, Sheehan J, Siebert S, Zaks DPM (2011) Solutions for a cultivated planet. Nature 478:337-342. doi:10.1038/ nature 10452

Giordan A (1997) Des modèles pour comprendre l'apprendre: de l'empirisme au modèle allostérique, http:/www.andregiordan.com/ articles/apprendre/modalost.html

Graur D (2007) Public control could be a nightmare for researchers. Nature 450(1156):20. doi:10.1038/4501156b

Habermas J (2002) in http://plato.stanford.edu/entries/truthcorrespondence/

Honneth A (2006) La société du mépris. Vers une nouvelle Théorie critique. La découverte/poche, Paris

Hubert B, Aubertin C, Billaud JP (2013) Recherches participatives, recherches citoyennes...une clarification nécessaire. Nat Sci Soc 21:1-2

Joly PB, Rip A (2007) A timely harvest. Nature 450(174). doi:10.1038/ 450174a

Kolb DA (1984) Experimental learning: experience as the source of leaning and development. Structural foundations of the learning process. Prentice-Hall, New-Jersey, USA Chap.3:1-42

Kuhn T S (1990) La tension essentielle. Tradition et changement dans les sciences. Gallimard, éditeurs

Lang DJ, Wiek A, Bergmann M, Stauffacher M, Martens P, Moll P, Swilling M, Thomas CJ (2012) Transdisciplinary research in sustainability science: practice, principles, and challenges. Sustain Sci 7(1):25-43. doi:10.1007/s11625-011-0149-x

Latour B (2009) Politics of nature - how to bring the sciences into democracy. Harvard University Press

Le groupe repère, les vignerons du syndicat de Westhalten, Moneyron A, Masson JE (2015) Revues des Vins d'Alsace, http:/www.inra.fr/ Grand-public/Agriculture-durable/Tous-les-magazines/ Mobilisation-des-viticulteurs-et-chercheurs-alsaciens-pour-1agroecologie

Legroux J (1989) Système personnel de production de savoir, in Pineau. Jobert, Histoires de vie Paris, L'Harmattan 2:217-229

Local Monitoring Committee, Lemaire O, Moneyron A, Masson JE (2010) "Interactive technology assessment" and beyond: the field trial of genetically modified grapevines at INRA-Colmar. PLoS Biol 30;8(11):e1000551. https://doi.org/10.1371/journal.pbio.1000551

Makepeace W, Dobson AT, Scott D (1985) Interference phenomena due to mouse-ear and king devil hawkweed. New Zeal J Bot 23:79-90

Malnoy M, Viola R, Jung MH, Koo OJ, Kim S, Kim JS, Velasco R, Nagamangala Kanchiswamy C (2016) DNA-free genetically edited grapevine and apple protoplast using CRISPR/Cas9 ribonucleoproteins. Front Plant Sci 20(7):1904. doi:10.3389/fpls.2016.01904 eCollection 2016

Marris C, Rose N (2010) Open engagement: exploring public participation in the biosciences. PLoS Biol 8(11). doi:10.1371/journal.pbio. 1000549

Moneyron A (1997) Reconnaissance et transmission culturelle des écosavoirs, in Reconnaître les acquis et valider les compétences. Revue Éducation Permanente 133:91-100

Moneyron A, Lemaire O, Masson JE (2012) Une expérience d'interaction science / société. Futuribles 283:111-118

Moneyron A (2013) Pratiques et savoirs d'agriculteurs en AB et de bergers/éleveurs face à l'aléa et au risque : l'apport des concepts d'écosavoir et d'écoformation pour expliciter les formes du savoiragir dans un monde incertain, in Agir en situation d'incertitude. Regards pluridisciplinaires au Nord et au Sud, Proceedings from the 2010 INRA/CIRAD-ss dir symposium

Morin E (2000) Les sept savoirs nécessaires à l'éducation du futur. Seuil, Paris

Pestre D (2013) À contre-science. Seuil, Paris

Phytowelt GmbH for the European Commission (2003) Study on the use of the varieties of interspecific vines: final report (Contract No. AGR 
30881 of 30/12/2002; http://ec.europa.eu/agriculture/markets/wine/ studies/vine_en.pdf)

Pineau G (1983) Produire sa vie. Edilig/Editions Saint-Martin, Montréal

Pineau G (1989) La formation expérientielle en auto-, éco- et co-formation, dans Apprendre par l'expérience. Revue Education Permanente 100/101:23-30. doi:10.7202/000123ar

Pineau G (2003) Vers une anthropo-formation en deux temps trois mouvements. Spirale, Revue de recherche en éducation 31:35-46

Prost L, Cerf M, Jeuffroy MH (2012) Lack of consideration for end-users during the design of agronomic models. A review. Agron Sustain Dev 32(2):581-594. doi:10.1007/s13593-011-0059-4

Romon M, Soustre-Gacougnolle I, Schmitt C, Perrin M, Burdloff Y, Chevalier E, Mutterer J, Himber C, Zervudacki J, Montavon T, Zimmermann A, Elmayan T, Vaucheret H, Dunoyer P, Masson JE (2013) RNA silencing is resistant to low-temperature in grapevine. PLoS One 8(12). doi:10.1371/journal.pone.0082652

Rose N (2012) Thinking on the edge. Democracy in the contemporary life sciences. BioSocieties 7(4):459-472. doi:10.1057/biosoc.2012.26
Schön DA (1994) Le praticien réflexif. À la recherche du savoir caché dans l'agir professionnel. Editions Logiques, Montréal

Smart DR, Schwass E, Alan Lakso A, Morano L (2006) Grapevine rooting patterns: a comprehensive analysis and a review. Am J Enol Vitic 57:89-104

Stefanini I, Dapporto L, Legras JL, Calabretta A, Di Paola M, De Filippo C, Viola R, Capretti P, Polsinelli M, Turillazzi S, Cavalieri D (2012) Role of social wasps in Saccharomyces cerevisiae ecology and evolution. Proc Natl Acad Sci U S A 109(33):13398-13403. doi:10. 1073/pnas. 1208362109

Stirling A (2012) Opening up the politics of knowledge and power in bioscience. PLOS Biol 10(1):e1001233. doi:10.1371/journal.pbio. 1001233

Tanentzap AJ, Lamb A, Walker S, Farmer A (2015) Resolving conflicts between agriculture and the natural environment. PLoS Biol 13(9): e1002242. doi:10.1371/journal.pbio.1002242

Wulf C. (1999) Anthropologie de l'éducation, Paris, L'Harmattan

Zeldin T (1999) De la CONVERSATION. Fayard, Paris 